J. Appl. Glycosci., 55, 1-3 (2008)

(C) 2008 The Japanese Society of Applied Glycoscience

Note

\title{
Synthesis and Structure Analysis of Glucosylpsicose Produced by Cyclomaltodextrin Glucanotransferase
}

\author{
(Received April 19, 2007; Accepted September 3, 2007) \\ Hisaka Oshima, ${ }^{1}$ Isao Kimura, ${ }^{1, *}$ Kenji Morimoto $^{2}$ and Ken Izumori ${ }^{2}$ \\ ${ }^{1}$ Food Research Institute of Kagawa Prefectural Industrial Technology Center \\ (587-1, Goutou-cho, Takamatsu 761-8031, Japan) \\ ${ }^{2}$ Rare Sugar Research Center, Kagawa University \\ (2393, Miki-cho, Kita-gun, Kagawa 761-0795, Japan)
}

\begin{abstract}
Glucosylpsicose was synthesized by transglycosylation with $\alpha$-cyclodextrin and D-psicose using cyclomaltodextrin glucanotransferase (EC 2.4.1.19; CGTase). The structure of glucosylpsicose was analyzed by HPLC to determine sugar composition and molecular mass, by methylation analysis using GC-MS and by $\alpha-$ and $\beta$-glucosidase treatments to determine linkage, and ${ }^{1} \mathrm{H}$ - and ${ }^{13} \mathrm{C}$-NMR spectrometries to obtain the anomeric configuration of the glycosidic linkage. By chemical analysis, it was found that the structure of glucosylpsicose is 1-o- $\alpha$-D-glucopyranosyl-D-psicose.
\end{abstract}

Key words: D-psicose, cyclodextrin, cyclomaltodextrin glucanotransferase

Recently, it has become apparent that D-psicose (D-psi) causes plant growth regulation effects and induction of defence gene transcription, ${ }^{1)}$ and provides no energy for growth in rats. ${ }^{2)}$ It might be expected that transglycosylation products with D-psi would have better functionality than the rare sugar itself, because oligosaccharides function as prebiotics, cosmetics and therapeutic materials. Previously, we designed some probable structures of xylosylpsicoses, which were synthesized by transglycosylation with arabinoxylan and D-psi using endo-1,4- $\beta$-D-xylanase (EC 3.2.1.8) from Aspergillus sojae.)

Here, we describe the preparation of glucosylpsicose (GP) produced by cyclomaltodextrin glucanotransferase (EC 2.4.1.19, CGTase). This enzyme is widely used in the synthesis of various glycosides. Evidence for the structure of the disaccharide is provided.

D-Psi was supplied by the Rare Sugar Research Center, Kagawa University. Cyclodextrin $(\alpha, \beta$ and $\gamma)$ and maltooligosaccharides (maltose, maltotriose, maltotetraose, maltopentaose, maltohexaose and maltoheptaose) were obtained from Hayashibara Biochemical Laboratories (Okayama). Dextrins Pinedex \#100, Pinedex \#4 and Pinedex \#1 were purchased from Matsutani Chemical Industry Co., Ltd. (Hyogo), and dextrin for chemicals (DEX) was obtained from Wako Pure Chemical Industries (Osaka). CGTase from Bacillus stearothermophilus was purchased from Seikagaku Corporation (Tokyo). $\alpha$ Glucosidase from rice, $\beta$-glucosidase from almonds, $\beta$ amylase from barley and amyloglucosidase from Rhizopus sp. were purchased from Sigma-Aldrich Corp. (St. Louis, MO, USA). Other chemicals were obtained from Wako Pure Chemical Industries.

* Corresponding author (Tel. +81-87-881-3177, Fax. +81-87-8829481, E-mail: kimura@itc.pref.kagawa.jp).

Abbreviations: Glcp, glucopyranose; Psip, psicopyranose; Psif, psicofuranose.
Transglycosylation products were analyzed with a Shimadzu HPLC System using a Shodex KS-802 column (Showa Denko, Tokyo; $0.8 \times 30 \mathrm{~cm}$ ). Unless otherwise specified, the transglycosylation reaction mixture containing $10 \mu \mathrm{L}$ of $25 \%(\mathrm{w} / \mathrm{w}) \alpha$-cyclodextrin $(\alpha-\mathrm{CD}), 10 \mu \mathrm{L}$ of $25 \%(\mathrm{w} / \mathrm{w}) \mathrm{D}$-psi in $50 \mathrm{~mm}$ sodium acetate buffer $(\mathrm{pH}$ 5.5) and $15 \mathrm{U}$ of CGTase was incubated at $40^{\circ} \mathrm{C}$ for $1 \mathrm{~h}$. The concentration of transglycosylation product was determined using isolated GP as a standard.

Figure 1 shows a chromatogram of the reaction products in the reaction mixture. With D-psi, a few new peaks - together with some peaks of hydrolyzates of $\alpha$ CD-were detected, since CGTase catalyzed not only transglycosylation (intermolecular and intramolecular), but also hydrolysis of $\mathrm{CD}$. ${ }^{5}$ From the result, we confirmed that GP was a major transglycosylation product under the reaction conditions.

The glucosyl donor specificity of the enzyme for producing GP is shown in Fig. 2. The enzyme acted on various glucosyl donors, e.g., maltooligosaccharides, CD and dextrins, to produce GP; glucose did not act as a substrate. The quantity of GP was increased with the increasing degree of polymerization (DP) of maltooligosaccharides. Among them, CD was a good glucosyl donor for the production of GP under the conditions used.

For isolation of GP, a reaction mixture containing $10 \mathrm{~g}$ of $\alpha-C D, 10 \mathrm{~g}$ of $\mathrm{D}$-psi and $5000 \mathrm{U}$ of CGTase in $15 \mathrm{~mL}$ of $20 \mathrm{~mm}$ sodium acetate buffer $(\mathrm{pH} \mathrm{5.5)}$ was incubated at $40^{\circ} \mathrm{C}$ for $24 \mathrm{~h}$. This reaction mixture $(10 \mathrm{~mL})$ was placed in a Toyopearl HW-40 S (Tosoh Co., Ltd., Tokyo) column $(5.0 \times 95 \mathrm{~cm})$ and eluted with distilled water. The fractions containing GP were concentrated, and the solution was separated using an $\mathrm{AG} 50 \mathrm{~W}\left(\mathrm{Ca}^{2+}\right)$ column $(2.6$ $\times 95 \mathrm{~cm}$ ) with distilled water as the eluent.

The purity and DP of the GP were analyzed using a Hypercarb column (Thermo Fisher Scientific Inc., Waltham, MA, USA; $0.46 \times 10 \mathrm{~cm}$ ) and a TSK gel G-oligo 




Fig. 1. Chromatogram of reaction products by CGTase from a mixture of $\alpha-\mathrm{CD}$ with or without D-psicose.

(A), with D-psicose; (B), without D-psicose; Psi, psicose; GP, glucosylpsicose; Glc, glucose.



Fig. 2. Glycosyl donor specificity for GP production.

G1, glucose; G2, maltose; G3, maltotriose; G4, maltotetraose; G5, maltopentaose; G6, maltohexaose; G7, maltoheptaose; $\alpha \mathrm{CD}, \alpha$ cyclodextrin; $\beta C D, \beta$-cyclodextrin; $\gamma \mathrm{CD}, \gamma$-cyclodextrin; SS, soluble starch; DEX, dextrin; \#100, pinedex \#100; \#1, pinedex \#1; \#4, pinedex \#4. The TG reactions with various glucosyl donors were carried out in a mixture containing $75 \mathrm{U}$ of CGTase, $50 \mathrm{mg}$ of Dpsicose and $50 \mathrm{mg}$ of various glucosyl donors in $0.25 \mathrm{~g}$ of $0.05 \mathrm{M}$ sodium acetate buffer $\mathrm{pH} 5.5$ at $40^{\circ} \mathrm{C}$ for $48 \mathrm{~h}$. Each value is presented as mean \pm SE of 5 samples. Values not sharing a common letter are significantly different by Student's $t$-test at $p<0.05$.

PW column (Tosoh), which was calibrated with standard glucose oligomers (DP 1-20; Seikagaku Corporation). The sugar composition of GP was analyzed according to the method of Pazur ${ }^{6)}$ using a Shodex KS-802 column with Dglucose and D-psi as standards.

From the purification steps, $c a$. $1.6 \mathrm{~g}$ of GP was obtained from $10 \mathrm{~g}$ of $\mathrm{D}$-psi in the reaction mixture; the yield of GP was $8.4 \%$ according to the following equation: transglycosylation product $(\mathrm{mol}) /$ acceptor $(\mathrm{mol}) \times$ 100. The isolated GP showed a single peak not only on the Shodex KS-802 column, but also on the Hypercarb column. Moreover, the DP of isolated GP was estimated to be two by a TSK gel G-oligo PW column. The sugar was hydrolyzed with $0.2 \mathrm{~N} \mathrm{HCl}$ at $100^{\circ} \mathrm{C}$ for $3 \mathrm{~h}$. The hydrolyzate was separated into glucose and psicose in a molar ratio of 1:1 by HPLC (data not shown).

Next, two mg of GP was methylated by the method of Hakomori. ${ }^{7}$ After extraction with chloroform, a methylated sample was hydrolyzed with $1 \mathrm{M}$ trifluoroacetic acid solution at $70^{\circ} \mathrm{C}$ for $30 \mathrm{~min}$, and the methylated monosaccharides were reduced with $1 \% \mathrm{NaBH}_{4}$ solution and then acetylated with acetic anhydride at $100^{\circ} \mathrm{C}$ for $3 \mathrm{~h}$. The
Table 1. Results of methylation analysis of glucosylpsicose.

\begin{tabular}{ccccc}
\hline Peaks & $\begin{array}{c}\text { Reten- } \\
\text { sion } \\
\text { time }\end{array}$ & $\begin{array}{c}\text { Methylated } \\
\text { sugar }\end{array}$ & $\begin{array}{c}\text { Linkage } \\
\text { site }\end{array}$ & $\begin{array}{c}\text { Rate of } \\
\text { composi- } \\
\text { tion }\end{array}$ \\
\hline P1 & 26.18 & 2,3,4,6-tetra- $o$-Methylglucitol & Glc $1 \rightarrow$ & 1.00 \\
P2 & 26.33 & 2,3,4,6-tetra- $o$-Methylallitol & $\rightarrow 1$ Psi & 1.06 \\
\hline
\end{tabular}

${ }^{*}$ The rate of composition of each methylated sugar was caluculated on the basis of the number of carbons from each peak as 2,3,4,6-tri-o-methylglucitol; 1.00 .

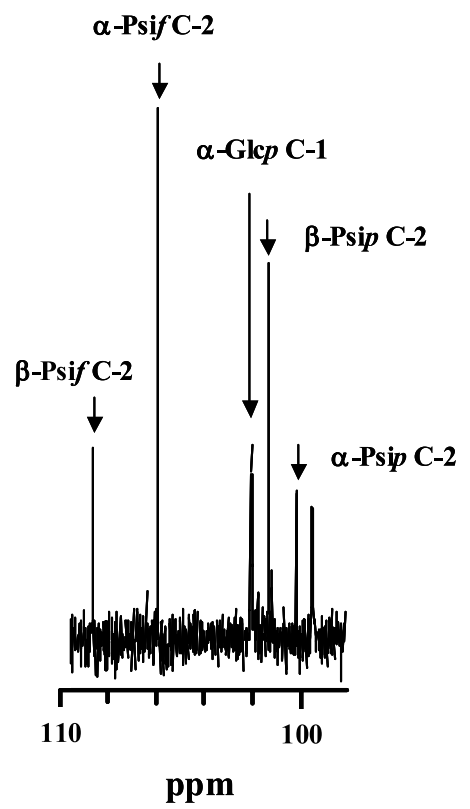

Fig. 3. ${ }^{13} \mathrm{C}-\mathrm{NMR}$ spectrum of GP

The ${ }^{13} \mathrm{C}$-NMR spectrum was recorded at $25^{\circ} \mathrm{C}$. Chemical shift is shown in ppm downfield from an internal sodium 3-(trimethylsilyl)$2,2,3,3-d_{4}$-propionate.

partial methylated alditol acetates were analyzed with a coupled system of gas chromatograph-mass spectrometry (GC-MS), namely, the Hewlett Packard HP5890 series II with an SPB-5 capillary column (Sigma-Aldrich Japan K. K., Tokyo; $25 \mathrm{~m} \times 0.25 \mathrm{~mm}$ internal diameter, I.D.) coupled to JEOL Auto-Mass system II (JEOL, Tokyo). The temperature profile for GC was as follows: hold initially for $1 \mathrm{~min}$ at $60^{\circ} \mathrm{C}$, wash and then increase to $280^{\circ} \mathrm{C}$ at a rate of $8^{\circ} \mathrm{C} / \mathrm{min}$. The MS conditions were as follows: electron impact mode $(70 \mathrm{eV})$ and a scanning rate of $1 \mathrm{~s} /$ scan.

Two major peaks (P1 and P2) were detected by GC under the described conditions; the peaks were identified as 2,3,4,6-tetra- $O$-methylglucitol and 2,3,4,6-tetra- $o$-methylallitol respectively, on the basis of the reported data ${ }^{8)}$ in a molar ratio of 1:1.06 (Table 1). These results indicated that the transglycosylation product was linked between the $\mathrm{C}-1$ positions of each sugar.

The ${ }^{1} \mathrm{H}$ - and ${ }^{13} \mathrm{C}-\mathrm{NMR}$ spectra were recorded with a JEOL NM-SCM 40 spectrometer; GP (40 mg) was dissolved in $0.6 \mathrm{~mL}$ of deuterium oxide $\left(\mathrm{D}_{2} \mathrm{O}\right)$ at $25^{\circ} \mathrm{C}$ with sodium 3-(trimethylsilyl)-2,2,3,3- $d_{4}$-propionate as the internal reference at $399.7 \mathrm{MHz}$ for ${ }^{1} \mathrm{H}-\mathrm{NMR}$ analysis and $100.4 \mathrm{MHz}$ for ${ }^{13} \mathrm{C}-\mathrm{NMR}$ analyses.

The signal at $5.1 \mathrm{ppm}$ signals in the ${ }^{1} \mathrm{H}-\mathrm{NMR}$ spectrum (data not shown) and the signal at $102 \mathrm{ppm}$ signal in the ${ }^{13} \mathrm{C}$-NMR spectrum were assigned to the anomeric proton 
and carbon of the C-1 of $\alpha-$ Glc $p$, respectively. Furthermore, the ${ }^{13} \mathrm{C}$-NMR signals at 100.2 and $101.3 \mathrm{ppm}$ were assigned to the $\alpha$ - and $\beta$-anomer of the C-2 of Psip, and those at 105.9 and $108.7 \mathrm{ppm}$ were assigned to the $\alpha$ - and $\beta$-anomer of the C-2 of Psif respectively, on the basis of the reported data ${ }^{9,10}$ (Fig. 3). These data indicated that the D-psi residue of GP was presented as mixtures of four tautomers, i.e. $\alpha$ - and $\beta$-Psi $p$, and $\alpha$ - and $\beta$ - Psif in the solution.

Additionally, GP $(0.5 \mathrm{mg})$ was incubated with $\beta$ glucosidase, amyloglucosidase, $\beta$-amylase or $\alpha$-glucosidase $(0.25 \mathrm{U}$ each $)$ in $200 \mu \mathrm{L}$ of $50 \mathrm{~mm}$ sodium acetate buffer $\mathrm{pH} 5.5$ for $18 \mathrm{~h}$ at $40^{\circ} \mathrm{C}$. Whereas no hydrolysis of GP under these conditions occurred with $\beta$-glucosidase, amyloglucosidase or $\beta$-amylase, $\alpha$-glucosidase caused hydrolysis of GP. From the chemical analysis, the structure of GP was identified as 1-o- $\alpha$-D-glucopyranosyl-Dpsicose.

Nakajima has already reported GP is produced from $\rho$ nitrophenyl $\alpha$-D-glucoside and D-psi by $\alpha$-glucosyltransferase from Protaminobactor rubrum. ${ }^{11)}$ Additionally, Morimoto et al. synthesized an $\alpha$-D-glucopyranose- $(1 \rightarrow$ 2)- $\beta$-D-psicofuranose using sucrose phosphorylase from Leuconostoc measenteroides with $\alpha$-D-glucosyl-1-phosphate and D-psi. ${ }^{12)}$ However, details of the structure of GP, which was produced by CGTase, are reported here for the first time. For industrial application of GP, the transglycosylation reaction with CGTase may be a useful method for mass production of GP, since the reaction uses a readily available $\alpha$-glucosyl complex, e.g., soluble starch, maltooligosaccharides and dextrin as a glucosyl donor.

In acceptor specificity of CGTase, Kitahata et al. reported the structure is an effective acceptor, which has the same configuration of the free C-2, C-3 and C-4 hydroxy groups as D-glucopyranose, and the transglycosylation product forms an $\alpha-1,4$-glucosidic linkage. ${ }^{13)}$ However, the linkage site of GP was the C-1 position of each sugar. Therefore, the mechanism of transglycosylation of glucosyl residue to D-psi was not based on the above mentioned factors, but it might be similar to that of ascorbic acid. ${ }^{14)}$ The acceptor specificity of CGTase for tautomers of D-psi and the efficient production of GP, and the elicitor effect on plants will be reported in due course.

This work was supported in part by a grant from the Technical Development Association Project (Sugar-Bio-Cluster) of the Kagawa Prefectural Government, Japan. We wish to thank Mrs. Noriko Kagawa, Food Research Institute of Kagawa Industrial Technology Center, for much helpful collaboration.

\section{REFERENCES}

1 ) K. Akimitsu, Y. Yamasaki, K. Fukumoto, B.G. Kim, K. Shimomura, M. Nomura, S. Tajima and K. Izumori: Effect of rare sugar for plant growth regulation and defense gene transcription: toward application of rare sugars in agriculture. in $A b$ stract Book of the 3rd Symposium of International Society of Rare Sugars, L12, Takamatsu, Kagawa, Japan (2006).

2 ) T. Matsuo, H. Suzuki, M. Hashiguchi and K. Izumori: DPsicose is a rare sugar that provides no energy to growing rats.
J. Nutr. Sci. Vitaminol., 48, 77-80 (2002).

3 ) S. Kitahata: Synthesis of oligosaccharides using microbial enzymes. Denpun Kagaku, 37, 59-67 (1990) (in Japanese).

4 ) H. Oshima, I. Kimura and K. Izumori: Synthesis and structure analysis of novel disaccharides containing D-psicose produced by endo-1,4- $\beta$-D-xylanase from Aspergillus sojae. J. Biosci. Bioeng., 101, 280-283 (2006).

5 ) S. Kitahata and S. Okada: Comparison of action of cylodextrin glucanotransferase from Bacillus megaterium, B. circulans, $B$. stearothermophilus and B. macerans. J. Jpn. Soc. Starch Sci., 29, 13-18 (1982).

6 ) J. H. Pazur: Neutral polysaccharides. in Carbohydrate Analysis, A Practical Approach, M.F. Chaplin and J.F. Kennedy, eds., 2nd ed., Oxford University Press, Oxford, New York, Tokyo, pp. 73-81 (1994).

7 ) S. Hakomori: A rapid permethylation of glycolipid, and polysaccharide catalyzed by methylsulfinyl carbanion in dimethyl sulfoxide. J. Biochem., 55, 205-208 (1964).

8 ) P.E. Janssen, L. Kenne, H. Liedgren, B. Lindberg and J. L̈̈nngren: A practical guide to the methylation analysis of carbohydrates. Chem. Commun., 8, 26-75 (1976).

9 ) K. Bock, C. Pederson and H. Pederson: Carbon-13 nuclear magnetic resonance spectroscopy of monosaccharides. Adv. Carbohydr. Chem. Biochem., 41, 27-66 (1983).

10) T. Katayama, A. Iwai, R. Kobori, T. Suzuki and K. Izumori: NMR of D-psicose and D-allose. in Proceeding of the Second Symposium of International Society of Rare Sugars, Takamatsu, Kagawa, Japan, pp. 347-350 (2004).

11) Y. Nakajima: Manufacture and utilization of palatinose. J. Jpn. Soc. Starch Sci., 35, 131-139 (1988) (in Japanese).

12) K. Morimoto, T.B. Granströ, G. Takata, M. Tokuda and K. Izumori: Rare oligosaccharide production by sucrose phosphorylase from Leuconostoc mesenteroides. in Abstract Book of the 3rd Symposium of International Society of Rare Sugars, P 33, Takamatsu, Kagawa, Japan (2006).

13) S. Kitahata, S. Okada and T. Fukui: Acceptor specificity of the transglycosylation catalyzed by cyclodextrin glycosyltransferase. Agric. Biol. Chem., 42, 2369-2374 (1978).

14) H. Aga, M. Yoneyama, S. Sakai, and I. Yamamoto: Synthesis of 2-O- $\alpha$-D-glucopyranosyl L-ascorbic acid by cyclomaltodextrin glucanotransferase from Bacillus stearothermophilus. Agric. Biol. Chem., 55, 1751-1756 (1991).

\section{シクロマルトデキストリン グルカノトランスフェラーゼを用いた グルコシルプシコースの合成と構造解析 \\ 大島久華 ${ }^{1}$ ，木村 功 ${ }^{1}$, 森本兼司 ${ }^{2}$, 何森 健 $^{2}$ \\ 1香川県産業技術センター食品研究所}

(761-8031 高松市郷東町 587-1)

2 香川大学希少糖研究センター

(761-0795 香川県木田郡三木町池戸 2393)

シクロマルトデキストリングルカノトランスフェラー ゼ (EC 2.4.1.19; CGTase) を用いて， $\alpha$-シクロデキストリ ンと D-プシコースからグルコシルプシコース (GP) を合 成した。GPの構造はHPLCによって糖組成と分子量, GC-MS を用いて結合部位を分析し， $\alpha$-グルコシダーゼお

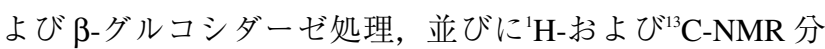
析によってグリコシド結合のアノマー構造を得た。化学 分析の結果から GP の構造は, 1- $-\alpha-\alpha-\mathrm{D}-$ グルコピラノシルD-プシコースであることが明らかになった。 